Author: Cl Tshoose

JUSTICE DELAYED IS JUSTICE DENIED: PROTECTING MINERS

AGAINST OCCUPATIONAL INJURIES AND DISEASES: COMMENTS ON

MANKAYI v ANGLOGOLD ASHANTI LTD 201132 ILJ 545 (CC)

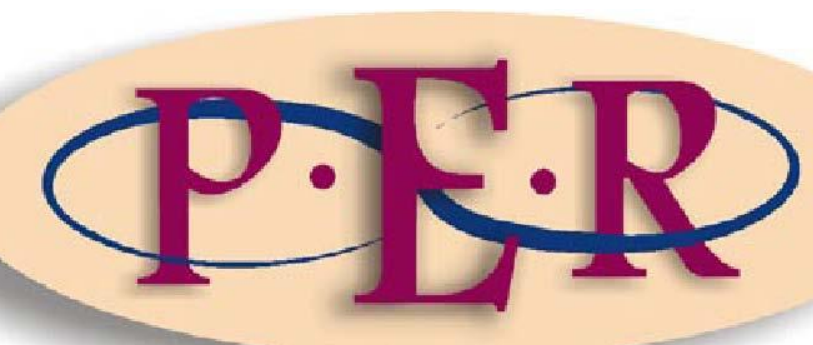

2011 VOLUME 14 No 7

http://dx.doi.org/10.4314/pelj.v14i7.10 


\section{JUSTICE DELAYED IS JUSTICE DENIED: PROTECTING MINERS \\ AGAINST OCCUPATIONAL INJURIES AND DISEASES: COMMENTS \\ ON MANKAYI v ANGLOGOLD ASHANTI LTD 201132 ILJ 545 (CC)}

Cl Tshoose*

\section{Introduction}

"Death is the constant shadow that haunts the ex-mine workers as they struggle for compensation." ${ }^{1}$ Linked to this are the poor working conditions that South African miners find themselves in. ${ }^{2}$ This is evident from the statistics of workers who die in accidents underground, while thousands more die of work-related diseases such as silicosis, ${ }^{3}$ which is a debilitating disease that causes scarring and shrinking of the lungs, destroying the breathing ability of people who suffer from it. ${ }^{4}$ Excessive exposure to dust and asbestos results in asbestosis and silicosis, which remain major causes of premature retirement and death among South African miners. ${ }^{5}$

Against this background, safety and health at work lie at the heart of the system of social security. The occupational health and safety system plays a crucial role in protecting employees against occupational injuries and diseases in their workplace. In fact, the occupational health and safety system has far-reaching implications for the contract of employment as well as in the lives of individuals, their families and communities. Recently, a number of scholars have addressed the impact of silicosis and asbestosis on the lives of mineworkers in South Africa. ${ }^{6}$

\footnotetext{
* Clarence Tshoose. LLB, LLM (North-West University). Senior Lecturer in Mercantile Law, College of Law, University of South Africa. E-Mail:tshooci@unisa.ac.za. The author would like to thank Ella Belcher (Chris Kapp Associates) and Jackie Viljoen for their editorial assistance in preparing this contribution.

1 York 2011 www.republicofmining.com.

2 SIMRAC 2003 researchspace.csir.co.za 24.

3 SIMRAC 2003 researchspace.csir.co.za 24.

4 Anonymous Date Unknonw jxzy.smu.edu.cn.

5 SIMRAC 2003 researchspace.csir.co.za 24.

6 McCulloch 2009 African Affairs 238-240; Ehrlich "Body as history"; Meeran 2003 IJOEH 218-227; Roberts Hidden Epidemic 32-39; Hermanus 2007 SAIMM 532-537.
} 
The purpose of this case note is to analyse critically the judgment of Mankayi $v$ AngloGold Ashanti, ${ }^{7}$ and to consider its implications for the system of occupational health and safety in South Africa. In this analysis, the main question is whether or not section 35(1) of COIDA, ${ }^{8}$ which excluded Mankayi from its scope of application, is constitutional. The contribution will analyse the decision of the Constitutional Court which dealt with the interpretation of section 100(2) of the ODIMWA ${ }^{9}$ and section $35(1)$ of COIDA. ${ }^{10}$

As a precursor, it is important to provide an overview of the Mankayi case for the discussion that follows. This will be done by analysing important legislation which plays a key role in occupational health and safety. Secondly, the case note will examine the system of compensation under the occupational health and safety legislation. Thirdly, the case note will be preceded by a short discussion of jurisdiction and prescription. Thereafter a discussion of the Mankayi case follows. As a point of departure, it will be argued that the decision of the Constitutional Court has far-reaching implications for the future of occupational health and safety, and in particular for the employer's liability for occupational injuries and diseases in mines.

\section{Brief overview of the Mankayi case}

The Constitutional Court in Mankayi v AngloGold Ashanti ${ }^{11}$ pondered the issue of the mineworkers' right to compensation. Firstly, the Court had to consider the provisions of section 100(2) of ODIMWA, which excluded Mankayi from claiming benefits under COIDA. Secondly, the Court had to decide whether section 35(1) of COIDA ${ }^{12}$ limits the right of mineworkers to recover damages for occupational injury sustained or disease contracted during the course of employment.

7 Mankayi v AngloGold Ashanti 201132 ILJ 545 (CC) (hereafter referred to as the Mankayi case).

8 Compensation for Occupational Injuries and Diseases Act 130 of 1993 (as amended by Act 61 of 1997).

9 Occupational Diseases in Mines and Works Act 78 of 1973 (hereafter referred to as ODIMWA).

10 Compensation for Occupational Injuries and Diseases Act 130 of 1993 (hereafter referred to as COIDA).

11 Mankayi case.

12 Section 35(1) COIDA states that no action shall lie by an employee or any dependant of an employee for the recovery of damages in respect of any occupational injury or disease resulting in the disablement or death of such employee against such employee's employer, and no liability for compensation on the part of such employer shall arise save under the provisions of this Act in respect of such disablement or death. 
It is against this background and on this basis (as discussed above) that the Applicant (Thembekile Mankayi) challenged the findings of both the South Gauteng High Court ${ }^{13}$ and the Supreme Court of Appeal ${ }^{14}$ in which section 35(1) of COIDA was interpreted as extinguishing the mineworkers' common-law right to sue the employer for occupational injuries sustained and diseases contracted during the course of employment, while protecting the employer against claims arising from non-compliance with the common-law duties of the employer, such as the duty to provide a safe working environment.

Judge Boshoff, in Van Deventer $v$ Workmen's Compensation Commissioner, ${ }^{15}$ summarised an employer's duty as follows:

\begin{abstract}
An employer owes a common law duty to a workman to take reasonable care for his safety. The question arises in each particular case what reasonable care is required. This is a question of fact and depends upon the circumstances of each particular case. A master [employer] is in the first place under a duty to see that his servants [employees] do not suffer through his personal negligence, such as failure to provide a safe working environment and a failure to provide [a] proper and suitable plant, if he knows or ought to have known of such failure.
\end{abstract}

The MHSA further places a duty on an employer to provide a safe working environment, and this duty is subject to the concept "reasonably practicable", which is defined in the Act.

In terms of the MHSA, the employer at a mine being worked at must ensure safety at the mine without risk to the health of employees and persons who may be affected by the activities at the mine. The MHSA also states that the appointment of a manager does not relieve the employer of any duty imposed on him by the MHSA or any other law. Furthermore, if no manager is appointed, the employer must himself perform the functions of the manager.

13 Mankayi $v$ AngloGold Ashanti Ltd Case No. 06/22312, South Gauteng High Court, Johannesburg, 26 June 2008, unreported.

14 Mankayi v AngloGold Ashanti Ltd 20105 SA 137 (SCA). This case was overruled by the Constitutional Court on appeal.

15 Van Deventer v Workmen's Compensation Commissioner 19624 SA 28 (T). 


\subsection{The facts}

In the present case, the Applicant had been employed as an underground mineworker by the Respondent (AngloGold Ashanti Limited) for 16 years from 1979 to 1995 . In his particulars of claim the Applicant alleged that during his employment the Respondent had negligently exposed him to harmful dusts and gases as a result of which he contracted diseases in the form of tuberculosis and chronic obstructive airways disease, which had rendered him unable to work as a mineworker or in any other occupation.

After being certified as suffering from a compensatable disease, the Applicant received R16 320.00 from the Compensation Commissioner in terms of ODIMWA. In enforcing his common-law right, the Applicant issued summons against the Respondent. He claimed damages in the sum of about R2.6 million. This comprised past and future loss of earnings of R738 147.14, future medical expenses of R1 374 600.00 and general damages of R500 000.00 (which included pain and suffering).

In the light of the above facts in the Mankayi case, both the High Court and the Supreme Court of Appeal ruled that the Applicant was barred by section 35(1) of the COIDA from instituting a delictual claim against his former employer, the Respondent. In fact, the Respondent raised a technical point, that the Applicant was barred by the operation of section 35(1) of COIDA from instituting a claim for damages against the Respondent. Section 35(1) of COIDA provides that:

an employee or any other dependent of an employee is precluded from recovering any damages in respect of any occupational injury or disease resulting in the disablement or death of such employee from such employee's employer. Section 35(1) also provides that no liability for compensation shall arise against an employer, except under COIDA.

In this case, the Respondent raised exception to the Applicant's claim, arguing that section 35(1) of COIDA barred the Applicant from claiming damages. The Respondent's exception was upheld by the High Court. The Applicant appealed the judgment of the High Court to the Supreme Court of Appeal. On appeal, the Supreme Court of Appeal found that section 35(1) of COIDA extinguished all common-law claims for damages for any occupational injury or disease resulting in 
the disablement or death of an employee and, consequently, that the Applicant's claim was excluded by s 35(1) (discussed above). In short, the Applicant's appeal was unanimously dismissed by the SCA bench. As a result, the Applicant approached the Constitutional Court on the following basis. Firstly, to determine whether section 100(2) of ODIMWA precludes the Applicant from claiming compensation under COIDA. It is important to note that section 100(2) provides that no person who has a claim to benefits, under ODIMWA, in respect of a compensatable disease, as defined in ODIMWA, on the ground that such person is or was employed at a controlled mine, shall be entitled, in respect of such disease, to benefits under COIDA, or any other law. Secondly, the Constitutional Court had to determine whether section 35(1) of COIDA includes employees covered by ODIMWA, notwithstanding that they are barred from claiming benefits under COIDA; and the abrogation of the common-law right of action envisaged by section 35(1) of COIDA.

\subsection{The decision of the Constitutional Court: Some preliminary remarks on prescription and jurisdiction}

\subsubsection{Prescription}

In the Mankayi case the Court was silent on the Prescription Act. ${ }^{16}$ However, it is important to give a brief overview of some of the relevant provisions of the Act which have some relevance to this case. The Prescription Act has the effect of extinguishing a debt after the lapse of a specified period. A debt in the context under discussion refers to the Applicant's claim for damages. The relevant period in this regard is three years. ${ }^{17}$ The question often arises when prescription commences. Must a plaintiff know all the facts on which his/her claim is based before prescription commences? Section 12 of the Prescription Act provides that prescription shall commence to run "as soon as the debt is due". ${ }^{18}$ However, if the defendant (a debtor) wilfully prevents the plaintiff (a creditor) from coming to know of the existence of the debt (the claim), prescription shall not commence to

16 Prescription Act 68 of 1969 (hereafter referred to as the Prescription Act).

17 Section 11 Prescription Act.

18 Section 12(1) Prescription Act. 
run until the plaintiff becomes aware of the existence of the claim. ${ }^{19}$ In Truter and Another $v$ Deysel, ${ }^{20}$ the court per Van Heerden, JA held inter alia as follows:

For the purposes of the Act, the term "debt due" means a debt, including a delictual debt, which is owing and payable. A debt is due in this sense when the creditor acquires a complete cause of action for the recovery of the debt, i.e. when the entire set of facts which the creditor must prove in order to succeed with his or her claim against the debtor is in place or, in other words, when everything has happened which would entitle the creditor to institute action and to pursue his or her claim.

Even though the Constitutional Court was silent on the issue of prescription, it is clear that the Mankayi case falls within the statutory confines of the Prescription Act, because the Applicant in his particulars of claim alleged that in 1993 and in 1999 he was diagnosed as suffering from pulmonary tuberculosis and that in August 2006 he was informed that he had contracted silicosis and obstructive airways disease. In my opinion, the discussion on the Prescription Act gives some guidelines on the time frames required by our law for a party to institute a claim against an employer.

\subsubsection{Jurisdiction}

The Constitutional Court was called upon to decide if it had jurisdiction to entertain this matter. In analysing the question of jurisdiction, the Court remarked that in a system of constitutional supremacy it is inappropriate to construe the concept of what is a "constitutional matter" narrowly. According to the Court, a constitutional matter involves the following: ${ }^{21}$

(a) the interpretation, application or upholding of the Constitution itself, (b) the development of (or the failure to develop) the common law in accordance with the spirit, purport and objects of the Bill of Rights, (c) a statute that conflicts with a requirement or restriction imposed by the Constitution, (d) the interpretation of a statute in accordance with the spirit, purport and objects of the Bill of Rights (or the failure to do so), (e) the erroneous interpretation or application of legislation that has been enacted to give effect to a constitutional right or in compliance with the legislature's constitutional responsibilities, or (f) executive or administrative action that conflicts with a requirement or restriction imposed by the Constitution.

19 Section 12(2) Prescription Act.

20 Truter $v$ Deysel 20064 SA 168 (SCA).

21 Mankayi case. 
In addition, as Khampepe $\mathrm{J}$ remarked, it is in the interest of justice that an authoritative interpretation be given to a statutory provision that is claimed to curtail an employee's common-law right to recover compensation for the harm suffered in consequence of an employer's negligence. This is so where the employee is not entitled to claim the benefits under that statute and can claim only seemingly paltry benefits under a different statute. ${ }^{22}$ Froneman $\mathrm{J}$, in delivering her reasons for granting leave to appeal, argued that the mere fact that this case concerns the interpretation of a statute is sufficient to bring it within the Constitutional Court's jurisdiction. ${ }^{23}$ Froneman states:

This constitutional injunction makes it impossible to interpret any legislation other than through the prism of the Bill of Rights. Statutory interpretation is thus inevitably a constitutional matter. It is a legal issue which necessarily involves the evaluation of social and policy choices reflected in legislation.

With reference to Pharmaceutical Manufacturers Association of SA and Another: In re Ex Parte President of the Republic of South Africa and Others, ${ }^{24}$ the Court observed that there is only one system of law. It is shaped by the Constitution, which is the supreme law, and all law, including the common law, derives its force from the Constitution of the Republic of South Africa, 1996 (the Constitution) and is subject to constitutional control. The Court further noted the decision in $S v$ Boesak, ${ }^{25}$ and Fraser v Absa Bank Ltd (National Director) Public Prosecutions as Amicus Curiae, ${ }^{26}$ and held that there are non-exhaustive instances of what constitute constitutional matters. The Constitutional Court further held that a constitutional matter can among other things include all questions of law which are derived from the Constitution. ${ }^{27}$

This approach to interpretation adopted by the Court suggests that as far as constitutional interpretation is concerned, South Africa is undergoing a

22 Mankayi case para 21.

23 Mankayi case paras 117-118.

24 Pharmaceutical Manufacturers Association of SA: In re Ex Parte President of the Republic of South Africa 20002 SA 674 (CC) para 44.

$25 S$ v Boesak 20011 SA 912 (CC) paras 10-5.

26 Fraser v Absa Bank Ltd (National Director); Public Prosecutions as Amicus Curiae 2007 SA 484 (CC) paras 35-47.

27 Mankayi case para 125. 
transformation from a formal, positivistic vision of law to a substantive, natural law vision of law.

\subsection{Analysis of and comment on the Mankayi case}

In the judgment delivered by Ngcobo CJ, Moseneke DCJ, Brand AJ, Cameron J, Froneman $\mathrm{J}$, Mogoeng $\mathrm{J}$, Nkabinde $\mathrm{J}$, Skweyiya $\mathrm{J}$ and Yacoob $\mathrm{J}$, the Constitutional Court overturned the previous judgment of the Labour Court and the Supreme Court of Appeal where it was held that section 35 of COIDA extinguishes the common-law right of mineworkers to recover damages for occupational injury or disease from negligent mine owners under COIDA. The South Gauteng High Court (High Court) ${ }^{28}$ and the Supreme Court of Appeal ${ }^{29}$ interpreted section 35(1) of COIDA as extinguishing the mineworkers' commonlaw claim and extending the protection against common-law liability to mine owners.

The Constitutional Court held that section 35(1), while excluding the common-law right of employees to sue the employer for damages in respect of occupational injury or disease, covers only employees who are entitled to claim under COIDA. Mineworkers excluded in terms of ODIMWA from claiming against their employer under COIDA for compensatable diseases in a controlled mine are not covered by section $35(1)$.

In justifying the conclusion it reached, the Court premised its argument on section 39(2) of the Constitution, which provides that a court must, when interpreting any legislation, promote the spirit, purport and objectives of the Bill of Rights. The Court per Froneman $\mathrm{J}^{30}$ reasoned that the interpretation given to section 35(1) of the COIDA in the High Court and Supreme Court of Appeal has the effect of abolishing a common-law right which protected and provided an appropriate remedy to the fundamental right to freedom and security of the person in terms of section 12(1) of the Constitution. One of the main issues

28 Mankayi v AngloGold Ashanti Ltd Case No 06/22312, South Gauteng High Court, Johannesburg, 26 June 2008, unreported.

29 Mankayi v AngloGold Ashanti Ltd 20105 SA 137 (SCA).

30 Mankayi case para 120. 
examined by the Court was the question of whether COIDA applies to employees covered by section 100(2) of ODIMWA, and whether the exclusionary and extinguishing effect of section 35(1) applies only to employees who have a claim for compensation under COIDA in respect of the occupational disease suffered by Mankayi. The Constitutional Court remarked that the meaning of the word "employee" in section 1 of COIDA covers employees such as the Applicant, who are entitled to claim for occupational diseases under COIDA and who may become entitled to claim benefits for compensatable diseases under ODIMWA. ${ }^{31}$

The Court also acknowledged that various provisions indicated that COIDA also applies to employees in controlled mines and works. The definition of the words "employee" and "employer" respectively do not expressly exclude employees who could have a claim for compensation under ODIMWA. ODIMWA provides statutory compensation for designated compensatable diseases contracted at controlled mines and works.

Apart from providing compensation for occupational injuries, COIDA also provides for statutory compensation in respect of a number of listed occupational disease $^{32}$ contracted by employees in the course of their employment and resulting in disablement or death. The diseases that constitute "compensatable diseases" under ODIMWA overlap with the diseases that constitute occupational diseases under COIDA. In the case of the Applicant, the disease which he had contracted could fall within both COIDA and ODIMWA, but section 100(2) of ODIMWA precludes him from claiming under COIDA. For the disablement set out in his particulars of claim, he is restricted to his ODIMWA remedy and is not entitled to a COIDA claim.

31 Mankayi case para 72.

32 Section 1 COIDA defines "occupational diseases" as any disease contemplated in s 65(1)(a) or (b). S 65(1)(a) refers to Schedule 3. Schedule 3 lists occupational diseases to include, inter alia, the following respiratory diseases:

(i) Pneumoconiosis-fibrosis of the parenchyma of the lung caused by fibrogenic dust;

(ii) Pleural thickening caused by asbestos dust exposure;

(iii) Silicotuberculosis;

(iv) Bronchopulmonary diseases caused by hard-metal dust;

(v) Bronchopulmonary diseases caused by cotton, flax, hemp or sisal dusts (byssinosis);and

(vi) Chronic obstructive pulmonary diseases. 
Furthermore, the Court also considered the impact of section 100(2) of ODIMWA on the definition of "employee" and the use of that word in section 35(1) of COIDA which provides:

... substitution of compensation for other legal remedies ... No action shall lie by an employee or any dependant of an employee for the recovery of damages in respect of any occupational injury or disease resulting in the disablement or death of such employee against such employee's employer, and no liability for compensation on the part of such employer shall arise save under the provisions of this Act in respect of such disablement or death.

What is striking in this provision is that there is no reference at all to ODIMWA, notwithstanding the fact that COIDA was enacted more than twenty years after ODIMWA. Had the legislature intended for ODIMWA to entitle employees to be covered under COIDA, it would have been easy for it to have included references to ODIMWA, but it has not done so.

It is, of course, important to be attentive to the precise language of the provision. What section 35(1) does in terms of the Court's interpretation is twofold. Firstly, it expunges the common-law claims of employees against the employer and, secondly, it limits an employer's liability to pay compensation save for under the Act. It expressly states that no liability for compensation on the part of such an employer shall arise save under the provisions of this Act.

It limits the employer's liability to pay compensation to liability under COIDA alone. That, in the Court's view, is an indication that both parts of the provision apply only to those employees covered by "the provisions of this Act"; namely, COIDA. Secondly, the Court emphasised that, if the language of section 35(1) is unclear, this Court would be entitled to have regard to the heading to determine its meaning. However, in the Court's view the language is clear, even without the heading. Section 35(1) substitutes COIDA compensation for other legal remedies and no more. Neither this provision nor any other in the relevant statute refers to compensation under ODIMWA.

According to the Court, the compensation provisions of ODIMWA and COIDA are separate but contiguous. While section 100(1) of ODIMWA precludes "double- 
dipping" on the part of employees who qualify for compensation because of having contracted a disease that is listed under both ODIMWA and COIDA, section 100(2) of ODIMWA goes further and specifically precludes employees with claims in respect of compensatable diseases under ODIMWA from claiming any COIDA benefits in respect of the same disease. It is difficult to see how section 100(2), while removing employees from COIDA compensation, could at the same time render section 35(1) applicable to them. Thirdly, the court analysed the comparison between COIDA and ODIMWA (see discussion at 2.4.1 below).

The Constitutional Court's decision in the Mankayi case, in my opinion, has farreaching consequences for employers, and also in the area of occupational health and safety. The Constitutional Court in this case should be commended for adopting a far-reaching and innovative way of developing the common law (discussed below). The Court's approach in developing the common law is informed by section 39(2) of the Constitution, which empowers the Court, when interpreting any legislation and when developing common law or customary law, to promote the spirit, purport and objects of the Bill of Rights.

This decision by the Constitutional Court imposes a duty on courts to ensure that, when faced with the task of developing common law, they do so in line with the Constitution. ${ }^{33}$ The Court's decision moreover imposes a duty on the courts to give effect to the tenets of the Bill of Rights. The Court developed the common-law rule in this decision, which resulted in the Respondent being made liable for the damages as a result of the exposure by the Applicant to harmful dusts and gases in consequence of which he contracted diseases in the form of tuberculosis and chronic obstructive airways disease, which have rendered him unable to work as a mineworker or in any other occupation.

The importance of this decision is extensive. It will surely change the way in which the courts deal with cases relating to compliance with occupational health and safety laws. It also deals successfully with the right to the freedom and

33 Section 39(2) Constitution. 
security of a person as enshrined in the Constitution. ${ }^{34}$

In this regard the Court referred to the matter of Law Society of South Africa and Others $v$ Minister for Transport and Another. ${ }^{35}$ In this case, the Court held that the abolition by the legislature of the common-law claim to sue a driver of a motor vehicle for negligent injury implicated the right enshrined in section 12(1)(c) and had to pass muster under the limitations provisions of the Bill of Rights. ${ }^{36}$ Similarly, the Court remarked that this same constitutional right finds expression in the legislation that seeks to regulate the safety of the mining industry, the Mine Health and Safety Act 29 of 1996 and the regulations prescribed thereunder.

\subsection{The protection of mineworkers against occupational injuries and diseases in South Africa}

There are various sources which regulate occupational injuries and diseases. The International Labour Organisation has a number of conventions concerning employment injuries and diseases. ${ }^{37}$ In South Africa a constitutional imperative regarding occupational health and safety exists. ${ }^{38}$ Collective agreements can also contain arrangements relevant to social security and health and safety at the workplace.

The primary legislation in South Africa which provides for preventative measures are Occupational Health and Safety Act, ${ }^{39}$ and the Mine Health and Safety Act, ${ }^{40}$ while

34 Section 12 Constitution.

35 Law Society of South Africa v Minister of Transport 20111 SA 400 (CC).

36 Mankayi case paras 75-78.

37 They include Convention on Minimum Standards of Social Security 102 of 1952, and the Convention on Benefits in the Case of Employment Injury 121 of 1964.

38 Section 24 Constitution states that everyone has the right to a safe working environment that promotes personal health and well-being. To put this in perspective, employers must identify workplace hazards, assess the potential risks stemming from these hazards and take appropriate action, which includes informing employees of the safety measures and risks associated with their workplace. For a detailed discussion on the employer's common law duties see Tshoose 2011 JICLT 166-171.

39 Occupational Health and Safety Act 85 of 1993 (hereafter referred to as OHSA).

40 Mine Health and Safety Act 29 of 1996 (hereafter referred to as MHSA). 
the most important legislation that regulates compensation for employees' injuries and diseases (and even death) suffered and contracted at work is the COIDA. ${ }^{41}$

There is also the ODIMWA, ${ }^{42}$ which provides for mandatory reporting and the payment of certain benefits to mineworkers who develop certain occupational lung diseases, as well as the payment of certain benefits for the dependants of workers who die from such diseases. The Road Accident Fund $A c t^{43}$ is applicable where an employee is injured while being conveyed by a motor vehicle in the course of his employment. In cases of commuting injuries, COIDA and the RAF Act must be read together. For the purposes of this contribution, however, the discussion is confined to COIDA, OHSA, and ODIMWA.

It is also important to note that the OHSA and the Mines Health and Safety Act are aimed at ensuring the health and safety of employees at the workplace. In essence, these statutes serve a truly preventative purpose in the sense that they strive to prevent the contraction of diseases or injuries by employees. Similarly, COIDA and ODIMWA deal with the aftermath of injury or disease, i.e. the payment of compensation to the injured employee.

The purpose of workers' compensation legislation was pointed out by Price $\mathrm{J}$ in $R v$ Canquan $^{44}$ when he remarked:

[Such legislation] is designed to protect the interests of employees and to safeguard their rights, and its effect is to limit the common-law rights of the employers and to enlarge the common-law rights of employees. The history of social legislation discloses that for a considerable number of years there has been progressive encroachment on the rights of employers in the interests of workmen and all employees. So much has this been the purpose of social legislation that employees have been prevented from contracting to their detriment. They have been prohibited from consenting to accept conditions of employment which the legislature has considered are too onerous and burdensome from their point of view.

In addition, COIDA is wider in scope than the Workmen's Compensation Act, which it replaced in 1993. Compensation is payable only if the accident which caused the

41 COIDA.

42 ODIMWA.

43 Road Accident Fund Act 56 of 1996 (hereafter referred to as the RAF Act).

$44 \quad R v$ Canquan 19563 SA 355 (E) 357-358. 
injury, illness or death occurred within the scope of the employee's employment and was not predictable. No payments are made in respect of temporary disabilities of three days or less. ${ }^{45}$

It is common that in most social security systems, even where a completely unified scheme for disability exists, a separate and more favourable scheme for industrial injuries is often retained. Occupational injury and disease benefits are not simply granted or allocated; they are bought through insurance contributions. Employees make available their labour to the employer who benefits from it financially. It is therefore accepted that the responsibility of financing such an insurance scheme rests with employers. In return, a statutory provision, such as section 35 of COIDA, replaces an employer's delictual liability towards the employee with insurance cover.

\subsubsection{Comparison between COIDA and ODIMWA on the levels of compensation}

The comparison between ODIMWA and COIDA compensation is aimed at proving that a person compensated under COIDA for an occupational disease is in a much better position than another person suffering from the same disease but who is compensated under ODIMWA. The Court, before coming to its conclusion, first compared the compensation payable under COIDA and ODIMWA respectively.

In terms of COIDA, an employee who suffers from an occupational disease is entitled to compensation in terms of Chapter VII of COIDA, which is headed "Occupational diseases". ${ }^{46}$ However, this Chapter does not exclusively concern itself with the mechanism for compensation, but sets out general principles. Section 65(6) of COIDA provides that the sections of COIDA regarding an accident apply "mutatis mutandis" to any occupational disease in relation to which there is a right to compensation in terms of COIDA. ${ }^{47}$ It is therefore necessary to revert to Chapter VI of COIDA, which is concerned with compensation for accidents. The court used the term "occupational disease" as used in Chapter VII. Employees who suffer from occupational diseases are not compensated in respect of the disease itself but for

45 Grogan Workplace Law 9.

46 Sections 65-70 COIDA.

47 Set out in s 65(1) read with Schedule 3 COIDA. 
temporary total disablement, temporary partial disablement and permanent disablement.

An employee who incurs temporary total disablement as from 1 April $2010^{48}$ would be entitled to receive up to 75 percent of his/her monthly earnings subject to a maximum of R16 400 and a minimum of R2 100 per month. ${ }^{49}$ The employer must pay this amount for the first three months of disability after which the Fund or the mutual association concerned takes over. ${ }^{50}$ The employee is entitled to 75 percent of his/her monthly earnings for a maximum period of 24 months, ${ }^{51}$ but this period may be extended in certain circumstances. ${ }^{52}$ This is particularly relevant to the ODIMWA comparison, which is made later, in that an employee who receives 75 percent of his/her monthly earnings for 24 months will in effect receive a total of one-and-a-half times his/her annual earnings and will return to work after that.

Employees who suffer permanent disability for the purposes of COIDA as a result of an occupational disease are in a much better position than the ones restricted to ODIMWA compensation. They are compensated according to the degree of their disability. The following examples, which were analysed by the court, demonstrate the gap between COIDA and ODIMWA in many respects:

(a) Employees who have a permanent disability of 30 percent are entitled to a lump sum of 15 times their monthly salary; that is to say, one-and-a quarter times their annual salary subject, as at 1 April 2010, to a minimum lump sum of R45 800 and a maximum of R183 $400 .{ }^{53}$ By contrast, the Applicant, who was diagnosed as suffering from a compensatable disease which rendered him completely unemployable, received a total of R16 320 under ODIMWA as calculated in 2005. Under COIDA he would have received R24 480 if he had been found to have been permanently disabled to a degree of 30 percent in 2005 .

48 The maximum and minimum amounts claimable are changed from time to time, but other details remain the same. For example see GN 304 in GG 33118 of 21 April 2010.

49 Section 47(1) and (2) COIDA read with item 1 of Schedule 4.

50 Section 47(3)(b) COIDA.

51 Section 47(5) COIDA.

52 Section 48(2) COIDA.

53 Item 2 of Schedule 4 COIDA. 
(b) Employees who suffer a 100 percent permanent disability are entitled to a monthly pension of 75 percent of their monthly salaries subject, as at 1 April 2010, to a minimum monthly pension of $R 2300$ and a maximum of R16 $400 .^{54}$ The Applicant would have received a minimum monthly pension of R1 224 under COIDA from 2005 and would by now have received in excess of R70 000 if he had been found to have been permanently disabled in 2005 . There is also a provision for the payment of a lump sum to this category of employee in certain circumstances. ${ }^{55}$

The dependant of an employee who dies as a result of an occupational disease would essentially receive in effect a lump sum of twice the monthly pension (a minimum of R4 600 as at 1 April 2010). ${ }^{56}$ The dependants would secondly benefit from a monthly pension of 40 percent of the amount that would have been payable to the employee had the employee been 100 percent permanently disabled. ${ }^{57}$ Thirdly, the Director-General would have to pay the employee's funeral costs subject to a maximum of R12 300 as at 1 April $2010 .^{58}$ Moreover, if the employer was negligent, the employee would receive more money and could in fact be compensated for his/her total financial loss. ${ }^{59}$ This concludes the overview of COIDA benefits in respect of occupational diseases.

The Court interpreted the relevant provisions of ODIMWA to the extent that it relates to COIDA. The Court emphasised that ODIMWA becomes applicable when an occupational disease is classified as a "compensatable disease". One would have expected the benefits under ODIMWA to be more or less the same or somewhat more than under COIDA, but the opposite is the case. Except for a person suffering from tuberculosis, who is entitled to 75 percent of his monthly earnings when ill, ${ }^{60}$ the only benefits payable to a person who is suffering from a compensatable disease

54 Section 49(1) COIDA read with item 4 of Schedule 4.

55 Section 52 COIDA.

56 Section 54(1)(a) COIDA read with item 6 of Schedule 4.

57 Section 54(1)(b) COIDA read with item 7 of Schedule 4.

58 Section 54(2) COIDA read with item 10 of Schedule 4.

59 Section 56(4)(b) COIDA.

60 Section 80(1) ODIMWA. 
contracted as a result of risk work is a lump sum which amounts to approximately one and one third of his annual salary ${ }^{61}$ if that employee suffers from a compensatable disease in the first degree, and about three times his annual salary ${ }^{62}$ if the compensatable disease is in the second degree. ${ }^{63}$

There is no provision for the payment of funeral expenses, or any lump sum or pension for dependants. The statute does, however, make provision for the dependants of a person who died of a compensatable disease to receive the lump sum that would have been payable to that person had he not died. ${ }^{64}$ In other words, where the person suffering from a compensatable disease has been paid the lump sum, the dependants get nothing even if they are children. To make matters worse, the person who finds himself afflicted with a compensatable disease merely because of legislative classification has no right to claim additional damages even if the employer was negligent, a right that is reserved for employees who suffer occupational diseases.

With this in mind, according to the Constitutional Court, the Supreme Court of Appeal erred in concluding that it is not possible to compare the two provisions. This is despite the fact that the differences between the compensatory regimes of COIDA and ODIMWA are quite apparent. A person whose disease is certified as a compensatable disease loses all the benefits of COIDA and receives much less under ODIMWA. ${ }^{65}$ The purpose is obviously to reduce the burden on the COIDA fund by converting an occupational disease into a compensatable disease. This means that the person benefits to a considerably lesser degree from another fund to which the employer makes a contribution and a much smaller contribution at that, because of the smaller benefits payable. The saving to the employer arising out of the redefinition of the disease amounts to a reduction in the contribution to the COIDA fund, which exceeds the amounts to be paid to facilitate the lesser compensation under ODIMWA. It must be emphasised that an employee who has a claim under ODIMWA has to be excluded from its scope of coverage. The drastic

61 Section 80(2)(a) ODIMWA, which provides for 1.31 of an annual salary.

62 Section 80(2)(b)(i) ODIMWA, which provides for 2.917 of an annual salary.

63 Section 80(2)(b)(i) ODIMWA.

64 Section 80(4) ODIMWA.

65 Mankayi case para 88. 
reduction in his compensation is obligatory. It is therefore not surprising that ODIMWA is silent on the issue of common law liability. ${ }^{66}$

The Court also commented on the enhanced compensation for which section 56 of COIDA provides where an employee contracts an occupational disease due to the negligence of the employer or other specified categories of related persons. ODIMWA has no comparable provision. ${ }^{67}$ This leaves those entitled only to ODIMWA compensation at a severe disadvantage. The argument that section 35(1) must be interpreted to exclude mineworkers' common-law claims so as to create a just and sensible parity in the two statutes' compensation systems is thus without merit.

In its conclusion the Court held that section 35(1) must be read in the context of the other provisions of COIDA. The employee referred to in section 35(1) whose common-law claim is expunged is limited to an employee who has a claim for compensation under COIDA in respect of occupational diseases mentioned in COIDA. It is this employee that section 35(1) of COIDA excludes from instituting a claim for the recovery of damages against the employer for occupational diseases resulting in disablement or death. The expungement does not extend to an employee who is not entitled to claim compensation in respect of "occupational diseases" under COIDA.

The corollary is that section 35(1) does not cover an employee who qualifies for compensation in respect of "compensatable diseases" under ODIMWA. The exclusion of liability in section $35(1)$ is therefore limited to employees who are entitled to compensation in respect of "occupational diseases" under COIDA. The exception raised by the Respondent should therefore have been dismissed.

The consequence of the judgment is that only employees who are precluded from claiming under COIDA as a result of the wording of section 100 (2) may now institute a claim of damages against their employer. The employee will still have the onus of proving damages and that such damages were caused by the negligence of the employer. This judgment does not mean that all employees at all mines and works

66 Mankayi case para 88.

67 Mankayi case para 107. 
will always have a right to bring claims for damages against their employer in respect of illness suffered in the course and scope of their employment. The application of ODIMWA is limited to certain compensatable diseases such as tuberculosis and permanent obstruction of the airways. Progressive systematic sclerosis and all other permanent diseases of the cardio-respiratory organs are included under ODIMWA only if they are attributable to the performance of risk work as defined under ODIMWA. The category of employees who fall within the ambit of section 100(2) is limited to those who claim under ODIMWA on the ground that they were employed at a controlled mine or a controlled works. In respect of tuberculosis ODIMWA deems risk work at any mine or works to be risk work performed at a controlled mine or works. The extent to which employees have to rely on the fact that they were employed at a controlled mine or works in order to be entitled to benefits is further not clear from the wording of ODIMWA.

\subsection{The significance of Mankayi v AngloGold Ashanti Ltd 201132545 (CC)}

The Constitutional Court's decision in the Mankayi case deemed to be relevant to the system of occupational health and safety based on the following reasons. Firstly, the Constitutional Court has developed a precedent to determine the content and meaning of the employer's duty of care. Phrased differently, there are yardsticks or standards of conduct against which the employer's conduct can be measured and judged. This judgment will instil some sense of accountability in employers who have exploited workers working under horrendous conditions for many years. Secondly, the judgment indicates that it is time the mines are taken to task about their responsibilities for the health and safety of employees in the workplaces. Lastly, the Mankayi case illustrates the difference in compensation that is being paid to employees suffering from the same occupational diseases. In short, it can be argued that the Mankayi case is the Court's latest and most promising innovation in the area of occupational health and safety.

In addition, in most civil-law jurisdictions the common-law duty of care is constantly being refined and given meaning and content by the courts through their judgments 
(as discussed above). ${ }^{68}$ In most countries the legislature has further refined the employer's duty of care by enacting health and safety legislation. In general, health and safety legislation is intended to give specific content to the duty of care, and to enhance accountability by providing for a range of additional criminal and administrative sanctions.

One of the criticisms levelled against this decision by the Constitutional Court is that this case will open the floodgates to many cases against the employers. However, in my opinion this decision of the Constitutional Court has the potential to achieve legislative change, in particular with regard to the protection of miners and ex-miners against occupational injuries and diseases. This resonates well with the constitutional provision which affords everyone the right to a healthy environment. ${ }^{69}$

The right to a healthy environment was first explicitly recognised as a non-binding principle in the 1972 Declaration of the United Nations on the Human Environment (the Stockholm Declaration) and the 1992 Rio Declaration on Environment and Development (the Rio Declaration). Those Declarations were not intended to create legal rights and obligations. However, they did contribute to the development of international and national law. The Stockholm Conference is considered an important starting point in developing environmental law at the global as well as national level. Principle 1 of the Stockholm Declaration linked environmental protection to human rights norms, stating:

Man has the fundamental right to freedom, equality and adequate conditions of life, in an environment of a quality that permits a life of dignity and well-being, and he bears a solemn responsibility to protect and improve the environment for present and future generations.

Principle 1 of the Stockholm Declaration established a further foundation for linking human rights and environmental protection, declaring that Man has the fundamental right to freedom, equality and adequate conditions of life, in an environment of a

68 The employer's duty of care in South Africa is the only mechanism whereby employers who breach the duty of care owed to their employees can be held accountable through a system of administrative sanctions regulated by the inspectorate and the criminal justice system. The civil justice system has no role to play. Indeed, it is expressly excluded.

69 Section 24 Constitution. S 24(a) affords everyone the right to an environment that is not harmful to their health or well-being. 
quality that permits a life of dignity and well-being. In resolution 45/94 the UN General Assembly recalled the language of Stockholm, stating that all individuals are entitled to live in an environment adequate for their health and well-being. The resolution called for enhanced efforts to ensure a better and healthier environment.

The interpretation of the above legal instruments clearly indicates a paradigm shift in the system of occupational health and safety in South Africa. The first one relates to the linkage between labour law and human rights. The second one indicates that the system of occupational health and safety cannot operate in isolation thereby disregarding other fundamental rights entrenched in the Constitution.

In fact, in other jurisdictions, the increased awareness of the constitutional right to a healthy environment has led courts to interpret the right to life as implying the right to a healthy environment in which to live that life. Authority illustrating this is found in the case of Taskin and Others $v$ Turkey. ${ }^{70}$ This case involved challenges to the development and operation of a gold mine which the Applicant alleged caused environmental damage to the detriment of the people in the region.

In deciding this case, the Turkish Supreme Administrative Court held that the member states must ensure appropriate protection of life, health, family, private property, and the human right to a healthy, viable and decent environment. In the second case of Tatar $v$ Romania ${ }^{71}$ which arose in the aftermath of an ecological disaster at a gold mine in Romania which resulted in high levels of sodium cyanide and heavy metals being released into fresh waters, the water caused pollution and local residents were affected. The court in its decision held that the government must take action to adopt reasonable and adequate measures capable of respecting the rights of individuals against serious risks to their health and well-being.

The implementation of occupational health and safety standards in the workplace has been a subject of debate at an international level. To begin with, South Africa has ratified two key conventions relating to safety and health: the Safety and Health

70 Taskin v Turkey App. No. 46117/99 2004 Eur Ct Hum Rts 621.

71 Tatar v Romania App. No. 67021/01 (judgment delivered in 27 January 2009). 
in Mines Convention ${ }^{72}$ and the Occupational Safety and Health Convention. ${ }^{73}$ The main objective of these conventions is to improve occupational safety and health conditions. $^{74}$

The implementation of occupational health and safety laws in South Africa leaves much to be desired. This is evident from the statistics of workers who die in accidents underground, while thousands more die of work-related diseases such as silicosis. ${ }^{75}$ Ladou $^{76}$ argues that corporation-dominated institutions will not implement meaningful worker-health protection. He therefore proposes a number of strategies to ensure that large corporations comply with occupational health and safety legislation. The author indicates that institutions such as the World Trade Organisation, World Bank, and the International Monetary Fund can play a key role in the implementation of the International Labour Orgnisation Conventions relating to occupational safety. One of the strategies that Ladou proposes is that the WTO, World Bank, and IMF can require member states to provide a minimum standard of workers' compensation insurance for all workers.

In short, multinational corporations, in particular in the area of mining, have a legal duty to comply with the Constitution and specifically with the provisions covering labour rights, environmental protection, and occupational health and safety as discussed above. Meeran ${ }^{77}$ argues that a duty should be imposed in respect of corporations operating in foreign countries to ensure that their operations do not violate workers rights to a safe environment.

Similarly, numerous methods of imposing human rights' accountability on corporations would be welcome. Such accountability should include the responsibility of the state for the actions of those within their jurisdictions. This means that in cases involving the violation of occupational health and safety laws, such a state could be held liable in international law for human rights' violations perpetrated by private

72 Convention on the Safety and Health in Mines 176 of 1995.

73 Convention on Occupational Safety and Health 155 of 1981.

74 Wilson 2007 Journal of Occupational Health 72-79.

75 SIMRAC 2003 researchspace.csir.co.za 24.

76 Ladou 2005 IJOEH 210-211.

77 Meeran 2000 IJOEH 249-254. 
entities, including corporations. ${ }^{78}$ Finally, the proposals for the inclusion of a human rights' (social clause) exception to free trade provisions under the WTO regime would improve compliance with occupational health and safety legislation.

\subsection{Conclusion}

In the Mankayi case, the Constitutional Court was called upon to give meaning and content by interpreting the provision whereby employees qualify for compensation for occupational injuries or diseases, either in terms of COIDA or ODIMWA, to determine whether or not their common-law right of recourse against their employers in cases where they sustain occupational injuries or contract occupational diseases is extinguished by virtue of section 35(1) of COIDA.

The Court noted that compensation under ODIMWA is far less generous and comprehensive than that afforded under COIDA and concluded that the exclusion of common-law liability in section 35(1) is limited to those employees entitled to compensation under COIDA. According to the Court, to hold otherwise would strain the plain meaning of the language in section 35(1). In its judgment the Court unanimously held that mineworkers who have contracted compensatable diseases under ODIMWA retain their common-law right to claim against their employers.

The above analysis has endeavoured to show the role that the Constitutional Court has played in protecting miners against occupational diseases. For that reason it is argued that the Constitutional Court has developed a precedent to determine the content and meaning of the employer's duty of care. This means there are yardsticks or standards of conduct against which employers' conduct can be measured and judged. This judgment will instil accountability in employers who have exploited workers for many years by expecting them to work under horrendous conditions. Secondly, the judgment indicates that it is time that mine owners were held to account for their responsibilities for the health and safety of their employees in the workplace.

78 Kinley and Joseph 2002 Alt LJ 7-10. 
In addition, in most civil-law jurisdictions the common-law duty of care is constantly being refined and given meaning and content by the courts through their judgments (as discussed above).$^{79}$ In most countries the legislature has further refined the employer's duty of care by enacting health and safety legislation. In general, health and safety legislation is intended to give specific content to the duty of care and to enhance accountability by providing for a range of additional criminal and administrative sanctions.

The judgment has attracted various criticisms. The critics of the Court charge it with "opening the flood gates" to cases against employers. However, there is a threefold answer to these critics. Firstly, this judgment, it is submitted, is groundbreaking in that it has paved the way for mineworkers to seek justice outside of the failed compensation system. Secondly, the decision of the Constitutional Court provides us with an opportunity to fight the legacy of asbestos and silicosis that has left a trail of health and death threats in our communities. Thirdly, the Mankayi case also highlights the lopsided nature of the workers' compensation laws in South Africa, which lean towards compensation and place little focus on human rights. On a positive note, the Mankayi judgment places a duty on the employer to implement numerous good practice solutions which will enhance safety in the workplace.

In conclusion, the Mankayi case illustrates an inherent gap in the system of occupational health and safety in South Africa. The Committee of Inquiry into a National Health and Safety Council concluded that the system of compensation under COIDA and ODIMWA has not maximised its potential to promote preventative activities. ${ }^{80}$ Even though it is more cost effective to run an effective rehabilitation scheme than to pay long-term cash benefits to victims of occupational accidents or diseases, reintegration measures are not being sufficiently addressed by the relevant South African legislation. ${ }^{81}$ It is evident that there is a need for a unified system

79 The employer's duty of care in South Africa is the only mechanism whereby employers who breach the duty of care owed to their employees can be held accountable. In practice it is through a system of administrative sanctions, regulated by the inspectorate and the criminal justice system, that the employer can be held accountable for non-compliance with his common law duties. The civil justice system has no role to play. Indeed, it is expressly excluded.

80 Olivier Social Security 491-499.

81 COIDA requires that the employer must pay the compensation due to the injured employee for the first three months of temporary total disablement (s 47(3)). This could perhaps be seen as a measure which will ensure to some extent the continuation of the employee's link with his 
which will address issues of occupational health and safety in a coordinated and unified manner.

employment. However, this remains essentially a temporary measure which is not backed by other (re)integration measures. 


\section{Bibliography}

Ehrlich "Body as history"

Ehrlich R 2007 "The body as history: On looking at the lungs of miners" (Inaugural lecture delivered at the University of Cape Town 26 September 2007)

Grogan Workplace Law

Grogan J Workplace Law $10^{\text {th }}$ ed (Juta Cape Town 2010)

Hermanus 2007 SAIMM

Hermanus MA "Occupational Health and Safety in Mining: Status, new developments and concerns" 2007 SAIMM 532-537

Kinley and Joseph 2002 Alt LJ

Kinley D and Joseph S "Multinational Corporations and Human Rights:

Question About their Relationship" 2002 Alt LJ 7-10

Ladou 2005 IJOEH

Ladou J "World Trade Organisation ILO Conventions, and Workers' Compensation" 2005 IJOEH 210-211

McCulloch 2009 African Affairs

McCulloh $\mathrm{J}$ "Counting the Cost: Gold Mining and Occupational Disease in Contemporary South Africa" 2009 African Affairs 221-240

Meeran 2000 IJOEH

Meeran R "Review Liability of Multinational Corporations: A Crucial Issue" 2000 IJOEH 249-254

Meeran 2003 IJOEH

Meeran R "Cape PIc: South African mineworkers' quest for justice" 2003 International Journal of Occupational and Environmental Health 218-227 
Olivier Social Security

Olivier MP et al Social Security: A Legal Analysis (LexisNexis Butterworths Durban 2003)

Roberts Hidden Epidemic

Roberts J The Hidden Epidemic Amongst Formers Miners: Report of the Department of Health (Department of Health Pretoria 2009)

Tshoose 2011 JICLT

Tshoose Cl "Employer's Duty to Provide a Safe Working Environment: A South African Perspective" 2011 6(3) JICLT166-171

Wilson 2007 Journal of Occupational Health

Wilson DJ et al "The Ratification Status of ILO Conventions Related to Occupational Safety and Health and Its Relationship with Reported Occupational Fatality Rates" 2007 Journal of Occupational Health 72-79

\section{Register of legislation}

Compensation for Occupational injuries and Diseases Act 130 of 1993 (COIDA) Constitution of the Republic of South Africa, 1996

Mine Health and Safety Act 29 of 1996 (MHSA)

Occupational Diseases in Mines and Works Act 78 of 1973 (ODIMWA)

Occupational Health and Safety Act 85 of 1993 (OHSA)

Prescription Act 68 of 1969

Road Accident Fund Act 56 of 1996 (RAF)

\section{Register of government pulibcations}

GN 304 in GG 33118 of 21 April 2010 


\section{Register of international treaties and instruments}

Convention on Benefits in the Case of Employment Injury 121 of 1964

Convention on Minimum Standards of Social Security 102 of 1952

Convention on Occupational Safety and Health 155 of 1981

Convention on the Safety and Health in Mines 176 of 1995

\section{Register of court cases}

Fraser v Absa Bank Ltd (National Director); Public Prosecutions as Amicus Curiae 20073 SA 484 (CC)

Law Society of South Africa v Minister of Transport 20111 SA 400 (CC)

Mankayi v AngloGold Ashanti Ltd 20105 SA 137 (SCA)

Mankayi v AngloGold Ashanti Ltd 201132 ILJ 545 (CC)

Mankayi v AngloGold Ashanti Ltd Case No 06/22312, South Gauteng High Court, Johannesburg, 26 June 2008, unreported

Pharmaceutical Manufacturers Association of SA: In re Ex Parte President of the Republic of South Africa 20002 SA 674 (CC)

$R v$ Canquan 19563 SA $355(\mathrm{E})$

$S v$ Boesak 20011 SA 912 (CC)

Taskin v Turkey App. No. 46117/99 2004 Eur Ct Hum Rts 621

Tatar $v$ Romania App. No. 67021/01

Truter $v$ Deysel 20064 SA 168 (SCA)

Van Deventer v Workmen's Compensation Commissioner 19624 SA 28 (T)

\section{Register of Internet sources}

Anonymous Date Unknonw jxzy.smu.edu.cn

Anonymous Date Unknown Occupational Health and Safety in Mining: Realities faced by mineworkers xzy.smu.edu.cn/.pdf [date of use 27 Sep 2011]

SIMRAC 2003 researchspace.csir.co.za

SIMRAC 2003 Final Report of the Safety in Mines Research Advisory Committee: Silicosis Control Programme - Phase 1, No SIM 02-06-03 
researchspace.csir.co.za/dspace/bitstream/10204/1302/1/Sim020603.pdf [date of use 4 Jul 2011]

York 2011 www.republicofmining.com

York G 2011 'South Africa's Sickened Gold Miners: A Long wait for Justice' Canadian Globe and Mail 20 June 2011 www.republicofmining.com/2011/06/20/for-south-africa\%E2\%80\%99ssickened-gold-miners-a-long-wait-for-justice-by-geoffrey-york-globe-and-mailjune-20-2011 [date of use 10 Jul 2011]

\section{List of abbreviations}

$\begin{array}{ll}\text { ALT LJ } & \text { Alternative Law Journal } \\ \text { Eur Ct Hum Rts } & \text { European Court of Human Rights } \\ \text { BCLR } & \text { Butterworths Constitutional Law Reports } \\ \text { COIDA } & \text { Compensation for Occupational injuries and Diseases Act } \\ \text { IJOEH } & \text { International Journal of Occupational Environmental Health } \\ \text { JICLT } & \text { Journal of International Commercial Law and Technology } \\ \text { MHSA } & \text { Mine Health and Safety Act } \\ \text { ODIMWA } & \text { Occupational Diseases in Mines and Works Act } \\ \text { OHSA } & \text { Occupational Health and Safety Act. } \\ \text { RAF } & \text { Road Accident Fund Act } \\ \text { ILJ } & \text { Industrial Law Journal } \\ \text { LAC } & \text { Labour Appeal Court } \\ \text { LC } & \text { Labour Court } \\ \text { SAIMM } & \text { Journal of Southern African Institute of Mining and Metallurgy } \\ \text { SCA } & \text { Supreme Court of Appeal }\end{array}$

